\title{
ALCANCES E LIMITES DO SINDICALISMO: CONTRIBUIÇÕES CRÍTICAS DE FRIEDRICH ENGELS E KARL MARX ${ }^{1}$
}

\author{
ALCANCES Y LÍMITES DEL SINDICALISMO: CONTRIBUCIONES CRÍTICAS DE \\ FRIEDRICH ENGELS E KARL MARX
}

\section{SCOPES AND LIMITS OF TRADE UNIONISM: CRITICAL CONTRIBUTIONS OF FRIEDRICH ENGELS E KARL MARX}

DOI: http://dx.doi.org/10.9771/gmed.v12i3.39065

\begin{abstract}
Michelangelo Marques Torres ${ }^{2}$
Resumo: O presente artigo pretende indicar o modo como Friedrich Engels e Karl Marx focalizaram a luta e a organização sindical no interior do conflito entre o capital e o trabalho, a fim de conduzirmos o andamento da análise para sua contribuição ao conjunto do marxismo, inclusive, demonstrando como o trabalho de Engels impactou sobremaneira as concepções formuladas por Marx nessa seara. Nesse sentido, faremos uma síntese das contribuições da obra de Marx e Engels no tocante ao tema do sindicalismo e apontando, quando possível, seus enfrentamentos com (variadas) concepções reformistas, centristas, anarquistas, autonomistas e burocráticas - conforme é possível notar, diferentes concepções de sindicato encontram-se disponíveis na literatura.
\end{abstract}

Palavras-chave: Sindicalismo; Consciência de classe; marxismo; Marx e Engels; natureza e processo de trabalho.

Resumen: Este artículo tiene como objetivo indicar cómo Friedrich Engels y Karl Marx se centraron en la lucha y la organización sindical dentro del conflicto entre el capital y el trabajo, con el fin de liderar el progreso del análisis por su contribución a todo el marxismo, incluyendo, demostrando cómo el trabajo de Engels impactó en gran medida las concepciones formuladas por Marx en esta área. En este sentido, haremos una síntesis de las contribuciones del trabajo de marx y engels sobre el tema del sindicalismo y señalando, cuando sea posible, sus enfrentamientos con (variados) reformistas, centristas, anarquistas, autonomistas y burocráticos - como se puede ver, una variada concepción diferente de la unión están disponibles en la literatura.

Palabras clave: Sindicalismo; Conciencia de clase; Marxismo; Marx y Engels; la naturaleza y el proceso de trabajo.

Abstract: This article aims to indicate how Friedrich Engels and Karl Marx focused on the struggle and the union organization within the conflict between capital and work, in order to lead the progress of the analysis for its contribution to the whole of Marxism, including, demonstrating how Engels' work greatly impacted the conceptions formulated by Marx in this area. In this sense, we will make a synthesis of the contributions of marx and engels' work on the theme of trade unionism and pointing out, when possible, their confrontations with (varied) reformist, centrist, anarchist, autonomistic and bureaucratic conceptions - as can be seen, different conceptions of union are available in the literature.

Keywords: Trade unionism; Class awareness; Marxism; Marx and Engels; nature and work process.

"A grande indústria concentra em um só lugar uma multidão de pessoas desconhecidas uma das outras. A concorrência divide os seus interesses. Mas a defesa dos salários, interesse comum frente ao patrão, une-as em uma ideia comum de resistência, de coalização" (Marx, Miséria da Filosofia).

"Se o industrial não contasse com uma oposição concentrada e maciça da parte dos seus operários, baixaria gradualmente, cada vez mais, os salários, para aumentar o seu lucro; a luta que tem de 
manter contra os seus concorrentes, os outros industriais, obriga-lo-ia a isso e em breve o salário atingiria o seu nível minimo". (Engels, A situação da classe trabalhadora na Inglaterra).

\section{Introdução}

O tema do socialismo e da consciência de classe revolucionária assume singular dimensão a partir das décadas de 1830-4033, e quem melhor sintetizou em termos teóricos esse processo foi, sem dúvidas alguma, Karl Marx. O texto político programático símbolo dessa nova etapa ideopolítica da luta de classes certamente é O Manifesto Comunista (em coautoria com Friedrich Engels), de 1848, o qual destaca inclusive a dimensão internacionalista da luta e da organização dos trabalhadores contra o movimento do capital ${ }^{4}$. Como assinala Arthur Rosenberg, "antes de 1848, em todos os países, a palavra socialismo tinha um sentido absolutamente inofensivo aos ouvidos dos homens" (ROSENBERG 1986). Desde então o socialismo ${ }^{5}$, que inclusive passaria a influenciar as lutas sindicais, procura superar (tanto em termos teóricos quanto em político-organizativos) tanto a luta corporativa quanto o isolamento local e regional dos movimentos da classe trabalhadora em diversos países.

Karl Marx e Friedrich Engels, os fundadores do socialismo científico, vivenciaram a época do surgimento e evolução dos sindicatos na Europa. Ao conferirem positividade no papel e diagnóstico dos sindicatos, também identificaram as limitações da luta de classes restrita ao campo sindical-corporativo no que se refere a perspectiva de superação da sociedade capitalista. Reconheceram que o sindicalismo é não apenas plenamente compatível com as relações sociais de produção burguesa como constitui um de seus próprios produtos históricos. Como destaca Alves (2003, p.123): "para Marx, os sindicatos faziam parte da própria natureza do capitalismo industrial e da condição do trabalho assalariado".

Este artigo pretende indicar como Friedrich Engels e Karl Marx abordaram o tema do sindicalismo, demonstrando suas possibilidades e também seus limites, no conjunto de sua obra. O artigo inicia apresentando a contribuição de Engels ao tratamento do tema sindicalismo para, em seguida, tratar da abordagem de Marx. O andamento expositivo procurará tratar da contribuição diferenciada de cada um dos autores fundadores do marxismo. Quando isso não for possível, isto é, quando a obra for conjunta (em co-autoria), a exposição se concentrará na parte relativa às contribuições de Marx. Ao final, apresentamos sinteticamente orientações ideológicas que influíram sobre distintas correntes sindicais ao longo do século XIX, bem como as considerações sobre o tema.

\section{A contribuição Engelsiana}

Ao estudar a materialidade objetiva da condição operária (dentro e fora das fábricas, incluindo, aqui, o espaço de reprodução social e a sociabilidade nas grandes cidades urbanizadas), o jovem Engels, em seu célebre $A$ situação da classe trabalhadora na Inglaterra [1845], se atenta à reação que os operários encontram às condições de vida ${ }^{6}$ que lhes eram impostas pelo capitalismo industrial em constituição. Apoiando-se nas diversas ações do movimento operário, Engels destaca três fases da rebeldia operária que antecedem o desenvolvimento dos sindicatos ${ }^{7}$. A primeira delas é a manifestação do crime, enquanto protesto individual, 
estéreo e inconsciente a manifestações da nova ordem social resultante da industrialização. A substituição de operários pelas máquinas gerou uma segunda fase de revolta operária no chão das fábricas em oposição à burguesia: o movimento luddista de destruição e quebra de máquinas como nova forma de resistência e revolta. Contudo essa segunda fase, ainda que superior, também se demonstrou limitada. O salto qualitativo se deu em fins do século XVIII, a partir da experiência das primeiras formas de organizações secretas operárias, consideradas ilegais. A luta pela liberdade de associação ganhou ímpeto e conquistou o reconhecimento jurídico apenas em 1824. Essa experiência resultou na terceira fase da organização proletária, que foi a existência de associações livres de uniões operárias (trade-unions), organizadas por ramos de produção. O objetivo era proteger o operário individual contra a sanha da burguesia. Essas associações espontâneas deram origem ao sindicalismo.

Em A situação da classe trabalhadora na Inglaterra, Engels revela a gênese da concepção marxista de sindicato, ao constatar a competição entre os próprios trabalhadores e seus esforços por suprimir tal concorrência por meio de associações: "Essa concorrência entre os trabalhadores, no entanto, é o que existe de pior nas atuais condições de vida do proletariado: constitui a arma mais eficiente da burguesia em sua luta contra ele" (ENGELS 2008, p.118). Na referida obra, o autor identifica na concorrência um elemento não apenas presente na competição intraburguesa, mas responsável por exercer influência entre a própria classe trabalhadora. Sob essa acepção, a concorrência constitui um dos elementos essenciais da sociabilidade burguesa, pressupondo a exacerbação do egoísmo e a fragmentação entre os trabalhadores. Os mecanismos de concorrência entre trabalhadores por postos de trabalho, no auge do período equivalente a Revolução Industrial inglesa, contribuiu para o rebaixamento de salários e o domínio do capital, especialmente com as mudanças processadas nas forças produtivas, como o investimento de capital fixo (maquinário-industrial). Assim entende Engels (2008):

Se o industrial não contasse com uma oposição concentrada e maciça da parte dos seus operários, baixaria gradualmente, cada vez mais, os salários, para aumentar o seu lucro; a luta que tem de manter contra os seus concorrentes, os outros industriais, obriga-lo-ia a isso e em breve o salário atingiria o seu nível mínimo.

Segundo Engels, no referido texto, as coalizões operárias seriam um primeiro passo no empenho de suprimir a concorrência. Sob esse aspecto, o fundador do marxismo atribui ao sindicalismo uma força social independente dos trabalhadores a fim de organizar a luta econômica e as greves da classe operária ${ }^{8}$. Entendidos por Engels como centros de organização de classe, os sindicatos cumpriam um duplo papel: não apenas amparar os trabalhadores, mas organizar o proletariado e educa-lo politicamente.

É, pois, de se perguntar: por que os operários entram em greve, dada a evidente ineficácia da sua ação? Simplesmente porque devem protestar contra a redução do salário e mesmo contra a necessidade de uma tal redução; devem expressar claramente que, como homens, não podem adaptar-se às circunstâncias, mas, ao contrário, as circunstâncias devem adaptar-se a eles, os homens - porque sua omissão equivaleria à aceitação dessas condições de vida, ao reconhecimento do direito de a burguesia explorá-los durante os períodos de prosperidade e deixa-los morrer de fome nos períodos desfavoráveis. Os operários protestam porque ainda não perderam os sentimentos humanos (ENGELS, 2008 p.252-253). 
Contudo ao reconhecer o valor das lutas imediatas, constata, logo em seguida, um elemento que podemos inferir como limite do sindicalismo: “(...) para destruir o poder da burguesia, é preciso algo mais que associações operárias e greves" (ibidem).

Distinguindo as estratificações no interior do proletariado, Engels chegou a atribuir ao setor operário industrial concentrado (ou proletariado fabril não especializado e pouco instruído) - a exemplo da indústria têxtil - o elemento de maior capacidade organizativa e sindical na Inglaterra do século XIX 9 . "Finalmente, uma observação: os operários fabris, em particular aqueles dos distritos onde se processa o algodão, constituem o núcleo do movimento operário" (ENGELS 2008 p.273), pois os operários da indústria ("a cabeça do movimento operário inglês") disporiam de maior consciência de seu interesse de classe $^{10}$. Contudo, apesar de identificar sua potencialidade e ser seu entusiasta, Engels atribui, no limite, um caráter defensivo à luta sindical por se processar no plano econômico-corporativo ${ }^{11}$ em nível local e profissional. A debilidade estaria no fato de que a luta sindical não altera os mecanismos de exploração do sistema capitalista. Outro limite da ação sindical identificado por Engels seria sua pouca relevância diante das crises cíclicas capitalistas, uma vez que a luta sindical se tornaria, em termos objetivos, impotente diante da estagnação industrial. Daí a importância de se conectar a luta sindical com a "luta política", esta identificada como um estágio superior na organização da classe.

Ao identificar uma certa ineficácia objetiva, um limite intransponível no sindicalismo submetido ao próprio movimento do capital, Engels atribui ao cartismo um caráter político mais abrangente, por se propor representar e lutar pelo conjunto da classe ${ }^{12}$. Ou seja, o parlamento também poderia ser palco de disputa da classe operária para conquistas democráticas e trabalhistas. Identificando no movimento cartista o embrião de um estágio qualitativamente superior da mobilização operária, ao transcender do chão da fábrica para o governo e o Estado a centralidade da luta, Engels reconhece a potencialidade política ${ }^{13}$ do movimento operário enquanto elemento ativo contra a sociedade burguesa.

Em The Labour Standard [1881], Engels dedica ao menos quatro artigos ${ }^{14}$ lembrando a função da luta sindical na organização da classe operária no que se refere à "lei econômica do salário", uma vez que “os salários dos operários não organizados tendem constantemente ao mínimo absoluto" (ENGELS apud Aguena, 2008 p.70). Diferentemente dos trabalhadores, “os capitalistas sempre estão organizados”. Em um deles, destaca que "a organização é a arma mais importante" que têm os operários. Os sindicatos já representavam, reconhece Engels, um poder que não pode ser ignorado por qualquer governo, seja liberal ou conservador. Ao mesmo tempo, Engels lembra o outro lado pendular da dialética, "os operários esqueceram seu poder de liderança da classe operária", em função disso, destacando a importância do Parlamento para a classe operária enquanto uma nova arma à disposição na luta de classes, que já poderiam “enviar ao Parlamento homens saídos da classe operária” (idem p.75).

Já em seu período de maturidade, Engels, em correspondência com August Bebel ${ }^{15}$, acerca da unificação dos partidos operários alemães - a Associação Geral dos Trabalhadores Alemães, sob influência de Ferdinande Lassale, e o Partido Social-Democrata dos Trabalhadores, dirigido por Wilhelm Liebknecht -, objeto de Marx, em Crítica ao Programa de Gotha [1875], aborda "a organização da classe trabalhadora como 
classe por meio de sindicatos", ao entender como essencial a luta dos trabalhadores nessas organizações "pois se trata propriamente da organização da classe do proletariado no seio da qual ele luta suas batalhas diárias contra o capital".

Engels, em 1881, conforme mencionado anteriormente, retomaria as bases científicas de Marx em sua crítica da economia política para lembrar, em um artigo intitulado Abolição do Sistema Assalariado, publicado no The Labour Standar, que a luta em torno de "um salário justo por uma jornada justa" seria em vão, pois o salário cumpre a função tão somente de fazer com que o operário adquira os "meios de subsistência necessários para mantê-lo em condições de trabalhar e de se reproduzir de acordo com as condições de vida de seu ambiente e de seu país" (ENGELS apud Aguena, 2008 p.82), até por que o capitalista se utiliza da intensificação da jornada de trabalho, e não necessariamente do seu prolongamento. Retomando Marx em O Capital, Engels lembra, no referido artigo, que "os salários do trabalho são pagos com trabalho, o operário é remunerado com o produto de seu trabalho" (ibidem p.83), uma vez que o capital não produz valor. Em outro artigo do mesmo período, O Sistema de Trabalho Assalariado, publicado no mesmo periódico, Engels reconhece o papel dos sindicatos como "indispensável", ainda que note que "os sindicatos não atacam o sistema de trabalho assalariado".

\section{A contribuição marxiana e sua co-autoria com Engels}

Segundo Alves (2003), similar a análise de Engels, há uma tensão interna nos escritos de Marx a respeito do tema sindicatos e sindicalismo, e não uma postura unilateral, em decorrência de seus fundamentos históricos, uma vez em que em seu legado teórico há presença da denúncia dos limites do sindicalismo, ao mesmo tempo em que se reconhece o valor da luta sindical enquanto "centro de organização da classe operária".

Ao destacar o papel econômico imediato do sindicalismo, Marx considera vital a atuação dos sindicatos na classe operária, os quais têm por finalidade "impedir que o nível dos salários desça abaixo da soma paga tradicionalmente nos diversos ramos da indústria e que o preço da força de trabalho caia abaixo de seu valor” (MARX e ENGELS, 1980, p.9). A lógica da atuação sindical consiste, portanto, em diminuir a "desigualdade de condições" entre patrão e empregado na regulamentação do contrato da venda da força de trabalho. Tratam-se de "sociedades de segurança" criadas pela classe trabalhadora, uma vez que "o capital é uma força social concentrada, enquanto que o operário não dispõe senão de sua força produtiva individual" (idem, p.13) ${ }^{16}$.Por outro lado, a principal atribuição dos sindicatos seria unificar os trabalhadores de uma categoria em torno de interesses convergentes, e coloca-los em luta contra os interesses patronais.

Em outubro de 1843, ao migrar para Paris, o jovem Marx, então com 25 anos, vivencia sua primeira experiência direta com o proletariado francês - após esse contato direto, nos primeiros meses de 1844, ano decisivo em seu percurso teórico-político ${ }^{17}$, em Introdução ao texto Crítica da Filosofia do Direito de Hegel [1843], Marx passa a tratar, ainda que em termos abstratos e filosóficos, do proletariado como sujeito social revolucionário. Um tratamento menos abstrato ao proletariado se daria meses posteriores, ao entrar em contato com a experiência concreta alemã da rebelião espontânea dos tecelões na Silésia, que impactaria 
decisivamente o jovem Marx, o qual publicou (em agosto de 1844) no jornal alemão Avante! (Vorwärts.), de tendência democrática, o artigo Glossas Críticas Marginais ao artigo "O Rei da Prússia e a Reforma Social" de um Prussiano [1844], em polêmica com Arnold Ruge ${ }^{18}$, abordando o tema da revolta dos trabalhadores contra as condições de trabalho e baixos salários.

Em A Sagrada Família[1844-5] encontram-se disponíveis algumas pistas indicativas do que pensavam Marx e Engels (embora o primeiro seja responsável pela redação da maior parte dos textos que compõem a obra) a respeito da identificação dos limites dos sindicatos ${ }^{19}$, ao reconhecer que aumento salarial, apesar de materialmente importante para os trabalhadores, representa, ao fim e ao cabo, uma negociação do preço da mercadoria força de trabalho. Apesar de atribuir um valor positivo para as coalisões de operários, Marx destaca que, do modo como estas se davam, não se questionava a lógica da propriedade privada dos meios de produção e as relações sociais de exploração do trabalho estranhado. Na referida obra os autores atribuem um potencial revolucionário ao proletariado, capaz de dissolver a "velha ordem", ao colocar a classe em movimento contra o capital, para além da luta sindical. Assim, a ação histórica do proletariado (MARX e ENGELS 2003) dá-se em função de sua própria situação social e da própria organização da sociedade burguesa ${ }^{20}$.

Entendimento similar encontra-se disponível no Manifesto Comunista [1848], quando Marx e Engels atribuem a importância das lutas imediatas se converterem - em unidades com lutas mais gerais - em lutas contra o capital e assumirem poder político, lembrando textualmente que, em função disso, é imperioso destacar que os comunistas, entendidos como vanguarda do proletariado, lutam "pelos interesses e objetivos imediatos da classe operária, mas, ao mesmo tempo, defendem e representam, no movimento atual, o futuro do movimento" (MARX e ENGELS, 2010 p.68). Em outro trecho da mesma obra destacam, ainda:

Mas em nenhum momento (...) se descuida de despertar nos operários uma consciência clara e nítida do violento antagonismo que existe entre a burguesia e o proletariado, para que, na hora precisa, os operários alemães saibam converter as condições sociais e política, criadas pelo regime burguês, em outras tantas armas contra a burguesia, para que logo após terem sido destruídas as classes reacionárias da Alemanha possa ser travada a luta contra a própria burguesia (MARX e ENGELS, 2010 p.69).

Assim, "o poder político é o poder organizado de uma classe para a opressão de outra" (idem p.59), e não meramente a reivindicação de melhorias nas condições de venda da força de trabalho de uma classe a outra. Esse seria o salto do economicismo para a dimensão da política de classe.

Em A Ideologia Alemã [1845], obra anterior ao Manifesto Comunista, também podem ser encontrados indicativos de gênese rudimentar do tratamento do jovem Marx a respeito do tema do sindicalismo, ao enfatizar que as uniões de operários aglomeram, no limite, trabalhadores assalariados como membros de uma classe (como indivíduos de classe), que em verdade não constituem indivíduos livres. Assim, observa-se que, em Marx, o tema sindicalismo assume relevância teórica à medida em que a constituição de seu sistema vai penetrando os modos de ser da sociedade moderna.

Contudo, é em A Miséria da Filosofia [1847] que se encontra disponível a primeira formulação de Marx a respeito do sindicalismo manifesta de modo mais evidente, enquanto objeto de tratamento teórico ${ }^{21}$. Ou seja, é nesta obra que Marx debruçou-se pela primeira vez nesse assunto (e que o sindicalismo se torna 
objeto de reflexão), ainda que, conforme demonstramos, tenha abordado espaçadamente o tema em suas obras de "juventude".

No referido texto, Marx destaca a importância dos sindicatos e das greves no seu caráter pedagógico, na experiência dos trabalhadores se organizarem em coletivo, cientes de que produzem a riqueza no modo de produção de mercadorias, avançando no processo de consciência de classe. Na referida obra é possível compreender o modo como Marx diferencia política e ideologicamente duas perspectivas influentes no meio operário e socialista: a reformista e a revolucionária ${ }^{22}$. A distinção é decisiva para analisar os movimentos sindicais em perspectiva ideopolítica. Ao polemizar com o utopismo reformista de Joseph Proudhon, o jovem Marx chega a conclusão - oposta ao mutualismo ou a perspectiva de conciliação de classes - da transformação revolucionária da sociedade capitalista, ao apresentar a formulação clara de um projeto comunista revolucionário.

Marx travou uma interessante polêmica com Proudhon, para quem as greves e os sindicatos seriam ineficientes ao revelarem uma luta pela elevação dos salários, visto que ainda que obtivesse êxito esbarraria na questão da inflação. Dito de outro modo, Proudhon afirmava, por exemplo, que a luta pelo aumento salarial resultaria na elevação dos preços. Marx, ao contrário, demonstrou que a luta pelo aumento dos salários implicava na redução dos lucros capitalistas (taxa de lucro). Ao afirmar a concepção materialista da história e refutar o conteúdo das formulações pretensamente científicas desenvolvidas pelo autor de Filosofia da Miséria ${ }^{23}$, Marx se ateria novamente ao tema em outras oportunidades ao enfrentar posições como a de Lassale, na Alemanha, em torno da Lei de Bronze dos Salários ${ }^{24}$, demonstrando a importância da luta econômica em estabelecer um salário mínimo necessário (físico e social) para a sobrevivência dos trabalhadores. Portanto, ainda que refute o desprezo proudhoniano a respeito das lutas por salários ${ }^{25}$, Marx reconhece o caráter limitado do sindicalismo: a luta econômica permanece restrita à lógica da regulamentação da exploração do trabalho e da melhoria do sistema de assalariamento, sempre passível às imprevisibilidades e a lógica da exploração. É nesse âmbito que o autor identifica a potencialidade de se avançar na luta sindical a partir de seus elementos políticos, uma vez que não se trata de uma luta com um fim em si mesma. "Não se diga que o movimento social exclui o movimento político. Não há, jamais, movimento político que não seja, ao mesmo tempo, social” (MARX, 2009 p.192). No mesmo sentido Engels destacaria no jornal The Labour Standar[1881]:

(...) a luta por altos salários e a redução da jornada de trabalho - para a qual se volta toda ação sindical no atual momento - não é um fim em si, senão um meio muito necessário e eficaz, mas somente um meio entre outros para atingir um fim mais alto: a abolição do sistema de trabalho assalariado (ENGELS apud Aguena, 2008 p.75).

Por isso, para Marx e Engels, a mobilização dos trabalhadores não deveria se limitar a defesa dos salários, empregos e redução da jornada de trabalho, embora fossem pautas imprescindíveis, mas deveria avançar com vistas à superação da lógica de exploração do capital sobre o trabalho, isto é, requer a luta política revolucionária para além da mera relação salarial.

Na década de 1850, Marx publica alguns artigos para o New York Daile Tribune. Nesta década, com a derrota do movimento operário e dos levantes democráticos de 1848 e a reação burguesa de caráter 
contrarrevolucionária, os sindicatos tendem a se integrar e se pautarem pelo método da conciliação. "Essa tendência moderada, cautelosa e prudente, que marcou a luta dos sindicatos, seria a linha predominante do movimento dos sindicatos pós-1850" (ALVES, 2003 p.144). Combatendo a "aristocracia operária" no interior do movimento sindical e operário, a exemplo da Amalgamated Society of Enginners, que contemplava os sindicatos de artífices especializados, de grande suporte financeiro, Marx destaca o valor dos sindicatos, ao mesmo tempo que seus limites. Nesses artigos, a fim de combater a apatia política e a guinada moderada do sindicalismo inglês, Marx afirma a importância do papel dos sindicatos e das ondas de greves "para se manter viva a combatividade da classe trabalhadora" e procurar "tê-la unida numa só grande organização" (MARX apud Alves, 2003 p.165), isto é, concebe o movimento sindical como ensaio para um futuro amadurecimento político do movimento operário. Com certos ganhos e concessões materiais para uma parcela minoritária do proletariado inglês, especializada e organizada em grandes sindicatos, houve a integração desse segmento minoritário da classe operáriaao sistema, especialmente por parte de lideranças operárias trade-unistas, que passaram a se afastar da tradição revolucionária e do cartismo. No mesmo período é também possível notar em uma correspondência de Engels a caracterização de que, dada a momentânea prosperidade econômica, "os operários se tornam aburguesados"26.

Nos anos 1860, a Associação Internacional dos Trabalhadores, ou Primeira Internacional, como ficaria posteriormente conhecida, desempenhou papel importante nas lutas sindicais. Segundo o próprio Marx, tratara-se de uma experiência política superior desempenhada pelo proletariado até então, a fim de unifica-lo, no interior de cada experiência nacional, em torno a um programa revolucionário. A ideia era dar ao movimento político do proletariado um caráter de classe, em perspectiva internacional. Segundo Marx, uma das tarefas centrais que a Internacional deveria desenvolver junto ao proletariado um sentimento de pertencimento de classe, e às organizações operárias uma solidariedade internacional. Por outras palavras, as lutas e as organizações operárias teriam que ganhar uma dimensão internacional.

Na resolução do III Congresso da AIT, elaborada por Marx e adotada em Bruxelas, em setembro de 1868 , identifica-se a importância e os limites de um dos principais instrumentos de luta dos trabalhadores organizados: as greves. Destaca, nesse sentido, que os sindicatos representam um meio de resistência dos trabalhadores e que "as greves não são um meio de emancipar completamente o trabalhador, mas uma necessidade na situação atual de luta entre o capital e o trabalho". Por um lado, trata-se da mobilização de uma organização econômica e corporativa sem a conquista do poder político por parte do proletariado, portanto limitada. O sindicalismo, nesses termos, luta contra o efeito do sistema, não contra suas causas. Por outro lado, a importância atribuída ao sindicalismo era tamanha que Marx e o Conselho Geral da Internacional impulsionavam o apoio e solidariedade das greves em diversos países, destacando que "A Associação Internacional dos Trabalhadores tem o dever de se solidarizar autêntica e efetivamente com essas organizações. Sua influência começa a se fazer sentir em toda parte" (ibidem, p.36) ${ }^{27}$. O entendimento era de que, num primeiro momento, as greves impulsionadas a partir dos sindicatos permitiam aos operários se constituírem enquanto classe e se organizarem coletivamente. Apenas a partir da constituição do proletariado em classe é que se seria possível projetar os operários a realizarem a sua organização política enquanto classe em oposição à classe burguesa e com vistas a triunfarem. 
Pode-se dizer que as resoluções da AIT contêm, de certo modo, a sistematização das contribuições de Marx acerca do sindicalismo. Em duras polêmicas e enfrentamento político com os campos proudhoniano e trade-unistas "puros" 28 , que limitavam o debate acerca dos salários e da jornada de trabalho (terreno economicista), o marxismo defendeu a luta sindical como importante meio de mobilização dos trabalhadores. Em julho de 1863 ocorreu a primeira assembleia do que viria a se constituir a fundação da AIT, em setembro de 1864, em Londres ${ }^{29}$. Conforme destaca Musto (2014, p.20):

Por meio dela, construiu-se o protótipo de todas as futuras organizações do movimento operário, um modelo que tanto reformistas quanto revolucionários tomariam, a partir de então, como ponto de referência: a Associação Internacional dos Trabalhadores.

A batalha política travada pelo marxismo na Primeira Internacional se deu com: a) a tática oportunista na esquerda operária (Lassale); b) a linha de sectarismo contra os sindicatos (posição antissindical); c) ideias autonomistas e anarquistas (Proudhon e Bakunin). Essa era a heterogeneidade das organizações que compunham a AIT. O sindicalismo inglês, de caráter reformista, restringia-se a questões de caráter econômico - melhorias das condições de trabalho no marco do sistema capitalista. Na França, Bélgica e Suíça Francesa prevaleciam os mutualistas - ancorados nas concepções de Pierre Joseph-Proudhon -, os quais tinham desacordo com a tática de greves como instrumento de luta e em relação ao envolvimento propriamente político dos operários. Antes disso, defendiam um sistema cooperativo, com acesso igualitário ao crédito. Estes constituíam a ala direita da AIT (MUSTO 2014). Articulado em torno das ideias de Karl Marx, os comunistas, campo anticapitalista que se opunha ao modo de produção vigente, identificavam na ação política independente do proletariado o potencial revolucionário para derrubada do poder burguês. Havia, ainda, segmentos independentes, não propriamente socialistas, de grupos de exilados de países do Leste Europeu, com destaque para o interclassismo de Giuseppe Mazzini. Por fim, havia ainda a presença de agrupamentos de trabalhadores franceses, belgas e suíços inspirados nas "confusas" ideias do utopismo (ibidem), bem como uma seção que não chegou a se associar à Internacional, embora sempre tenha "girado em sua órbita" (MUSTO, 2014, p.22).

Coube a Marx ${ }^{30}$ proferir o discurso inicial de abertura, além de ser o encarregado de redigir os estatutos da Associação Internacional dos Trabalhadores, a qual assumiu um caráter de Frente Única Operária, um instrumento de coordenação da iniciativa sindical e política da classe operária, em defesa das greves em curso e da campanha por legislação trabalhista progressiva. Em seu interior, travou um permanente combate contra o oportunismo e o sectarismo ${ }^{31}$, como indica o sugestivo subtítulo da obra de Sagra (2010). Nesse empreendimento, Marx se empenhou em combater as fileiras dos mutualistas e seguidores de Robert Owen na I Internacional - e fora dela, em sua órbita, os lassalianos alemães -, obtendo êxito no reconhecimento da função essencial dos sindicatos. Marx entendia que a organização de coalizões cada vez mais amplas e gerais (não parciais) de operários poderia elevar o movimento operário ao patamar de constituição do proletariado enquanto classe, em unidade cada vez mais ampla. Nesse sentido, as associações operárias não seriam um fim em si, mas um meio na passagem das lutas imediatas e pontuais para lutas operárias de caráter nacionais que visem o poder político, isto é, transitando das lutas econômicas às lutas políticas. Conforme observou Alves (2003, p.139): “A prática de luta dos sindicatos é posta para se negada, 
enquanto movimento operário parcial, limitado, de forma radical, pelas próprias condições criadas pelos mecanismos da economia capitalista".

Uma conferência proferida por Marx dá origem, em 1865, a Salário, Preço e Lucro32. Em polêmica com as posições de John Weston (owenista, membro da Internacional), os lassallianos e os proudhonianos, que condenavam o sindicalismo e a luta por salários nos debates da Internacional, Marx, por entender que "os sindicatos trabalham bem como centros de resistência contra as usurpações do capital" (MARX 2010 p. 141), defende a importância imediata da ação sindical enquanto luta necessária e "inseparável" do sistema de trabalho assalariado ${ }^{33}$, ao mesmo tempo em que aponta os limites da luta econômica ${ }^{34}$, destacando, por exemplo, que a redução da jornada de trabalho requereria uma ação política de nível parlamentar ("intervenção legislativa"), como a legislação fabril, que tocasse nos interesses gerais da classe operária em conjunto. Marx defende que tais lutas devem estar subordinadas a uma luta política geral da classe trabalhadora, à defesa da abolição do regime de assalariamento. Assim, os sindicatos teriam o potencial de ser "centros de organização da classe operária", cumprindo o papel de "alavanca", ainda que somada a outros esforços políticos, para a emancipação da classe. Tal unidade operária seria um preâmbulo para combater se combater, e não apenas resistir, ao "poder social concentrado do capital".

O Congresso de Genebra de 1866 confirmou a importância dos sindicatos para a Internacional, havendo destaque para as posições de Marx em oposição, ainda, a corrente mutualista. Os mutualistas defendiam posições "moderadas", como a que "o trabalhador seria, ao mesmo tempo, trabalhador, capitalista e consumidor" (MUSTO, 2014 p. 32), sustentado por um sistema de concessão de crédito gratuito enquanto medida de transformação do capitalismo, além de condenarem qualquer regulamentação do Estado entre a relação trabalho versus capital, inclusive a redução da jornada de trabalho - identificado, erroneamente, como elemento de fortalecimento do poder governamental em detrimento do interesse dos trabalhadores. Nessa acepção, a emancipação econômica dos trabalhadores decorreria da adesão a cooperativas de produção, e não pela socialização dos meios de produção ou qualquer outra forma de intervenção do Estado - seja qual fosse seu caráter de classe. A tendência mutualista era refratária, ainda, ao instrumento sindical de greves.Por outras palavras, os mutualistas eram pela conciliação de classes, e não pela abolição das mesmas ${ }^{35}$. Apenas após o Congresso da Basileia é que a Internacional abandonou o mutualismo na França, erradicando a influência do proudhonismo ${ }^{36}$ e reafirmou a importância da luta sindical na classe operária. A esse respeito, referindo-se a à luta econômica, como a defesa dos salários e a limitação da jornada de trabalho - somada a necessidade da coordenação internacional dos sindicatos - Marx e a Internacional destacaram ser "preciso generalizá-la, fundando e organizando sindicatos em tosos os países" ${ }^{37}$. Em 1871, em entrevista ao Word ${ }^{38}$, Marx lembraria recomendaria "ajuda da Internacional ao movimento sindical", destacando que a AIT teria o dever de se solidarizar com os sindicatos.

É em O Capital que identificamos os fundamentos científicos para os limites do sindicalismo (ALVES 2003). Ao expor a Crítica da Economia Política, Marx chega a indicar elementos sobre a ação política do proletariado em algumas passagens, ainda que não tenha dedicado uma seção específica ao tema. Destaca, por exemplo, que a luta sindical corporativa e local é limitada, pois para o processo de produção da mais-valia não é o trabalbo concreto (seja ele qualificado ou não-qualificado ${ }^{39}$ ), produtor de valores de uso, que 
é determinante, mas o trabalho abstrato ${ }^{40}$ destituído de sua particularidade, ao passo que a organização sindical se limita a organização dos trabalhadores restritos ao âmbito do "trabalho concreto" e suas negociações com o poder concentrado do capital a partir de um tipo específico e particular de manifestação do ciclo produtivo. A ação sindical realiza-se em defesa da regulação do preço da força de trabalho de uma categoria profissional, e não a sua abolição para o conjunto da classe. Nesse sentido, a luta por um "preço justo" para a jornada de trabalho não transformaria o regime de assalariamento e exploração do trabalho, posto que o salário sempre se refere à composição do "trabalho necessário", trabalho-pago, deixando, no limite, intocável, a parte relativa ao "trabalho excedente", trabalho não-pago. Por outras palavras, o capitalista remunera o trabalhador apenas após o mesmo ter contribuído com o processo de produção de mais-valor, que será consumido pelo próprio capitalista, como também após ter produzido o seu próprio valor enquanto capital variável. O salário, enquanto forma-mercadoria, versa numa parcela do valor produzido pela força de trabalho empregada, consiste, ainda, em produto de trabalho. Contudo, em decorrência da aparência fenomênica das relações de produção capitalistas ${ }^{41}$, o fetichismo da mercadoria-salário e do dinheiro ocultam essa relação social de produção de riquezas e exploração do trabalho ${ }^{42}$, uma vez que o salário aparece aos trabalhadores como se independessem de sua produção e existissem à margem dos produtores, na esfera da circulação.

\section{Considerações finais}

Logo se nota, os últimos textos de Marx e Engels também não passaram imunes ao tema do sindicalismo. Conforme nos esforçamos em demonstrar, Marx e Engels, ao mesmo tempo que indicaram elementos de potencial organizativo na luta sindical, nunca deixam de destacar, especialmente Marx, as limitações da luta de classes no terreno econômico. Em Salário, Preço e Lucro Marx conclui a esse respeito:

Os sindicatos trabalham bem como centros de resistência contra as usurpações do capital. (...) Mas são deficientes, de modo geral, por se limitarem a uma luta de guerrilhas contra os efeitos do sistema existente, em lugar de, ao mesmo tempo, se esforçarem para transformá-lo, em lugar de empregarem suas forças organizadas como alavanca para a emancipação final da classe operária, isto é, para a abolição definitiva do sistema de trabalho assalariado (MARX, 2010, p.141).

Distintamente das inúmeras correntes influentes no meio operário e das variações das correntes socialistas, o marxismo postula o fim da sociedade de classes e a abolição do assalariamento e da exploração do trabalho pelo capital, a partir da tomada do poder do Estado - que deveria transitar seu caráter de classe, do poder burguês para o operário ${ }^{43}$ - pelo proletariado organizado enquanto sujeito social do processo histórico revolucionário. A transformação social, segundo o materialismo histórico-dialético, é fruto de determinadas condições históricas, e o poder proletário requer a mediação do partido operário revolucionário na direção do processo revolucionário para a realização do socialismo, o qual requer, por sua vez, um caráter internacional e transitório, rumo ao comunismo. A luta sindical e econômica dos trabalhadores em um ramo produtivo nacional seria o embrião, um primeiro estágio de mobilização política e de construção da consciência de classe a partir de reivindicações imediatas da classe trabalhadora. Nesse sentido, na acepção marxiana e engelsiana, apesar de cumprir um papel importante na luta de classes, os 
sindicatos não substituem o partido - entendido com a classe em movimento, organizada sob um programa político e uma direção revolucionária-, e este, não substitui a classe trabalhadora. Na esteira de Marx, afirma Engels serem os sindicatos "a escola de guerra dos trabalhadores, nas quais eles se preparam para a grande luta que não pode ser evitada". Mas, lembrando os ensinamentos dos fundadores do marxismo, "escola de guerra" não é a guerra propriamente (ENGELS 2008).

Em síntese, a contribuição de Marx e Engels - que estiveram limitados ao contexto histórico do século XIX, especialmente a emergência do capitalismo concorrencial-liberal e o período de ascensão das relações capitalistas de produção (não tendo, desse modo, presenciado o chamado sindicalismo de massas ${ }^{44}$ ) - destaca limites na forma-sindicalismo (ALVES 2003), mas também visualiza, potencialidades de suas organizações, do ponto de vista objetivo e subjetivo. Objetivamente, a luta sindical obtém êxito nas lutas imediatas por dentro do capitalismo, trazem conquistas materiais inclusive. O ponto de vista subjetivo está ancorado no elemento pedagógico da unidade da luta que confere ao trabalhador certa identidade e pertencimento de classe, possibilitando uma consciência não fragmentada de seus interesses. Foi por isso que Marx se envolveu numa batalha política-ideológica contra as tendências que negavam a importância da luta sindical e econômica dos trabalhadores, sejam abordagens conservadora-reacionárias ou aquelas reformistas ou, ainda, sectárias, atuantes no seio operário. Superou tanto os argumentos dos economistas liberais quanto o dos socialistas utópicos e anarquistas.

Podemos destacar outras concepções sindicais influentes no sindicalismo europeu do século XIX e início do XX. Além da já mencionada concepção trade-unista de sindicalismo, vinculada e restritas às reivindicações predominantemente econômicas, desenvolveu-se, especialmente em países com proletariado industrial menos concentrado no período, a corrente auto-intitulada "revolucionária", precursora do anarquismo (ANTUNES 1985). Os "sindicalistas revolucionários" apostavam na luta exclusivamente econômica e na greve geral espontânea para transformar radicalmente a sociedade, com destaque para Georges Sorel, na França, e Labriola, na Itália, exercendo influência também em países como Espanha e EUA (BIHR 2010). Sorel, superestimando a ação espontânea das massas, negava veementemente a luta política ou qualquer forma de organização partidária, apresentando uma visão antiestatista. $\mathrm{O}$ "sindicalismo revolucionário" de inspiração anarquista (por vezes denominado, equivocadamente, por anarcosindicalismo) tinha reservas em recorrer ao Estado para satisfazer interesses do proletariado, uma vez que, nesse entendimento, a luta política não poderia passar pelo Estado, tampouco pela conquista do poder político. Apostavam na ação direta ${ }^{45}$, no antilegalismo e no antiparlamentarismo, recusando qualquer "substitutivo" organizativo. Apostavam na greve geral insurrecional como forma de impulsionar a expropriação direta e a auto-gestão.

Outra variante libertária a destacar, da mesma tendência anarquista, que identificava na luta sindical e na autogestão a possibilidade de emancipação da sociedade e descartava a atuação política e negava qualquer forma de organização ou forma de Estado, era expressa por Piotr A. Kropotkin e Errico Malatesta, sob influência do já mencionado Proudhon. Ainda que não fosse uma corrente homogênea, identificava no sindicato (entendido como um fim em si mesmo) o núcleo-base, o embrião organizativo, da sociedade anarquista. Avesso às direções políticas e às "estruturas verticais", defendiam a estrutura sindical 
"horizontalizada", a partir da autonomia organizacional dos sindicatos, sem mediações com partidos, vistos como "correias de transmissão" dentro dos sindicatos. O já mencionado Mikhail Bakunin, foi expressivo adepto do anarco-sindicalismo, ao reivindicar os sindicatos como a organização autêntica das massas e contra qualquer forma de administração estatal.

Antunes (1985) lembra, ainda, a corrente do sindicalismo cristão, inspirada na encíclica Rerum Novarum (1891), de Leão XIII. A vertente cristã, apoiando a organização sindical conciliadora, que não defende transformações radicais, fundamenta-se na "função social do capitalismo", no sentido de humanizar as suas sequelas sociais, rejeitando a atuação com base na luta de classes. Por fim, lembramos a corrente corporativista, datada das primeiras décadas do século $\mathrm{XX}$, oriunda do fascismo italiano que reprimiu e liquidou o movimento operário e suas lideranças, tendo sido apoiada na manipulação das massas populares. Esta linha do sindicalismo corporativo visava ideologicamente sua conciliação com o capital (por isso participam patrões e empregados), sendo subordinada e dependente do Estado fascista. Sua organização é decorrente da Carta Del Lavoro, de 1927, idealizada pelo ditador Benito Mussolini - que influenciou o sindicalismo corporativo da era Vargas no Brasil. Outra variante da mais influente é expressa pela corrente reformista, a qual nos deteremos criticamente mais adiante. Em síntese, a concepção reformista sindical recusa um "sindicalismo político" e se limita a estreita defesa dos interesses econômico-corporativos, adequando-se ao capitalismo.

Conforme sabemos, já no Manifesto Comunista, Marx e Engels deram uma dura batalha contra o campo reformista enquanto parte da estratégia comunista - sobretudo se notarmos a terceira seção. Em diversos textos e situações políticas, conforme pudemos desenvolver, consolidaram uma perspectiva revolucionária que contemplasse a flexibilidade tática para a intervenção dos sindicatos. Simultaneamente, apontam as potencialidades e limitações dos sindicatos na luta de classes, importante instrumento de luta dos trabalhadores organizados por melhores condições de vida e pela ampliação de direitos, mas incapaz de oferecer por si mesmo uma alternativa para a superação da ordem do capital.

Em tempos em que os desafios do momento histórico atual impostos aos sindicatos são enormes, em contexto de evidente ofensiva reacionária e devastação do mundo do trabalho em diversas partes do mundo, notadamente a realidade brasileira, Marx e Engels podem ser insuficientes, dadas suas limitações históricas, mas imprescindíveis para buscar-se o fortalecimento e ampliação dos espaços de lutas junto aos sindicatos, potencializando as instâncias organizativas da classe e contribuindo para o avanço da sua consciência.

\footnotetext{
Notas:

${ }^{1}$ Este texto é uma versão modificada de um capítulo do livro em que tivemos oportunidade de desenvolver o tema: "Trabalho, Sindicalismo e Consciência de Classe", Marília-SP: Lutas Anticapitalistal, 2020.

2 Professor efetivo de Sociologia do IFRJ. ORCID: https://orcid.org/0000-0001-9093-2677 Email: michel1848@yahoo.com.br

3 "A consciência de classe dos trabalhadores ainda não existia em 1789, durante a Revolução Francesa. Fora da Grã-Bretanha e da França, ela era quase que totalmente inexistente em 1848. Mas nesses dois países ela certamente passou a existir entre 1815 e 1848 , mais especificamente por volta de 1830" (COGGIOLA 2010 p.64).
} 
4 "Pode-se afirmar que o Manifesto tem centralidade no desenvolvimento da tradição marxista, em particular para o seu pensamento político" (BRAZ, 2011 p.29). No mesmo sentido, trata-se do documento "mais influente desde a Declaração dos direitos do homem e do cidadão, da Revolução Francesa" (HOBSBAWN, 1998 p.294).

5 Como é sabido, o termo socialismo é bem mais antigo. Mas é apenas com o avanço das formas de luta e da experiência da classe operária contra as contradições do modo de produção capitalista (fruto do processo histórico da Revolução Industrial inglesa, transição do século XVIII para o XIX) e do seu tratamento científico que adquire tal conotação.

${ }^{6}$ Degradação física, moral, social e intelectual.

7 "A revolta dos operários contra a burguesia seguiu de perto o desenvolvimento da indústria e atravessou diversas fases" (ENGELS, 2008 p.248).

8 Engels destaca que as greves operárias funcionam como “escola de guerra” (ENGELS, 2008 p.259) ao desenvolverem junto aos trabalhadores a coragem de enfrentamento com a burguesia e a solidariedade de classe (identidade e pertencimento de classe).

9 Como é sabido, a Inglaterra foi a "oficina do mundo" do capitalismo industrial, entre os séculos XVIII e XIX. Ocorre um progressivo crescimento do movimento sindical, especialmente após 1824, com a legalização das associações sindicais (trade-unions) até então na condição de clandestinidade, e que com a supressão do decreto proibitivo das associações, ganham amplitude em toda Inglaterra. Com o reconhecimento legal das organizações sindicais, "os operários se converteram numa potência, na Inglaterra. (...) Daí, as explosões de ódio da classe capitalista dessa época contra os sindicatos” (MARX e ENGELS, 1980 p.39). Conforme observa José Paulo Netto, a consolidação do mundo burguês é, ao mesmo tempo, a articulação de sua negação: “O protesto operário descreve uma curva ascendente até os anos de 1840. Conquistada a legalidade da organização sindical na Inglaterra (1824), manifesta-se, na ilha, a tendência operária à associação: multiplicam-se as reuniões, federações etc., que serão catalisadas, entre 1838 (data da publicação da Carta do Povo) e meados da década seguinte, pelo movimento cartista, cuja experiência constitui o primeiro legado para os futuros partidos políticos operários” (NETTO, 2009, p.14-15).

10 Alves (2003, p.54) afirma que, ao passo que o proletariado industrial não especializado e pouco instruído de Manchester tendesse a apoiar o cartismo, enquanto movimento político, os artífices especializados se restringiam ao campo do sindicalismo, enquanto luta no plano dos interesses meramente econômicos, por salários e jornadas - o sindicalismo era mais forte em Londres entre os artífices especializados. Cabe lembrar, conforme vimos, que os sindicatos da época eram organizados por ofício.

11 Indicando os limites políticos do sindicalismo no que se refere a emancipação do proletariado, bem como a necessidade da organização dos trabalhadores superar a luta sindical e econômica, Engels destaca igualmente a importância da classe operária participar do Parlamento ao mesmo tempo em aponta a necessidade de se compreender "(...) que a luta por altos salários e a redução da jornada de trabalho - para onde se volta toda a atuação sindical no atual momento - não é um fim em si, senão um meio muito necessário e eficaz, mas somente um meio entre outros para atingir um fim mais alto: a abolição do sistema de trabalho assalariado” (MARX e ENGELS, 1980, p.44). Conferir Engels em The Labour Standard, órgão dos sindicatos ingleses, em 1881.

12 Em termos políticos, o movimento cartista condensaria a luta e a oposição proletária à classe capitalista. "O cartismo é a forma condensada da oposição à burguesia" (ENGELS, 2008 p.262). Uma comissão da Associação Geral dos Operários de Londres (London WorkingMen's Association) condensou 6 pontos de reivindicações populares em torno da Carta do Povo, em 1838, sob liderança de William Lovett, dentre as quais estavam presentes demandas de vários agrupamentos operários por sufrágio universal (para homens), renovação anual do parlamento, remuneração parlamentar a fim de que trabalhadores sem recursos pudessem exercer mandatos, voto secreto, suspensão de voto censitário (posse de propriedades fundiárias) como condição para elegibilidade na Câmara Baixa (Parlamento Inglês). O movimento cartista se arrefeceu na década seguinte. Importante registrar que Engels não identificava o cartismo como um fim em si mesmo, apesar de representarem legitimamente o proletariado: “Os seis pontos (...) para o proletário não são mais que meios” (idem, p.269).

13 E não o alcance defensivo dos sindicatos, como as meras lutas econômicas.

14 Artigos publicados no The Labour Standard, Abolição do sistema assalariado, O sistema do trabalho assalariado, Sobre os Sindicatos (I) e Sobre os Sindicatos (II), datados, respectivamente, de 07.05.1881, 21.05.1881, 28.05.1881 e 04.06.1881. Os dois primeiros artigos serão lembrados mais adiante. A ênfase, aqui, remete-se aos dois últimos.

15 “Friedrich Engels a August Bebel” correspondência datada de 18-28 de março de 1875, Londres. In: MARX (2012 p.55).

16 Esta última citação é parte da redação da Resolução da Associação Internacional dos Trabalhadores (AIT) sobre os sindicatos, redigida por Marx, que ao acompanhar a evolução do movimento sindical no século XIX indica a perspectiva de se filiar os sindicatos ao que ficaria conhecida como a Primeira Internacional Socialista, da qual trataremos adiante.

17 Datam do mesmo ano a redação de seus trabalhos Sobre a Questão Judaica e Manuscritos Econômico-Filosóficos, este último nunca publicado em vida.

18 Ruge argumentava que a insurreição havia sido algo localizado e isolado politicamente, expressão de irracionalidade de pobres tecelões, pois segundo o autor, na Alemanha não haveria nenhuma disposição para uma reforma social, até porque, nessa perspectiva, a miséria dos resultados da industrialização não era um ponto generalizável em toda a Alemanha. Por isso, defendia a tese segundo a qual uma revolução social na Alemanha seria impossível, e, assim, a rebelião dos tecelões na Silésia não ofereceria qualquer perigo ao rei. Marx, distintamente, identificava na referida insurreição uma expressão da luta de classes, pois a rebelião não era contra o rei, mas contra a burguesia. Apesar de ser um episódio parcial expressava um caráter geral da luta de classes moderna, tendo o protagonismo do proletariado naquele protesto contra a condição proletária. Apesar disso, Marx tinha a clareza de que essa condição não poderia ser transformada por meios políticos, mas por meios sociais. Ver a crítica à política e à ideia de emancipação política em oposição à emancipação social (humana), contida nos referidos textos de 1844.

19 Ainda que Marx e Engels tratem muito esporadicamente do tema da "união de operários" em A Sagrada Família, há passagens que contém alguns indicativos sobre a temática sindical.

20 Não é secundário destacar que em 1845 Marx e Engels viajam por seis semanas à Inglaterra a fim de colher dados de pesquisa, realizar leituras e, no caso de Marx, ter contato direto com o movimento operário inglês e seus dirigentes políticos, a exemplo dos

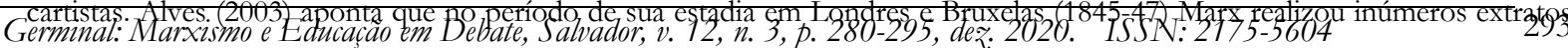


de leituras de economistas e historiadores sobre a temática do mundo do trabalho, a exemplo da oscilação dos salários e os fundamentos das greves, com destaque para três extratos de obras que tematizam ou circundam o tema do sindicalismo, a saber, Chartism de Thomas Carlytle, History ofthe Middle and working classes de John Wade e On Combination of Trades, um extrato de Engels sobre o sindicalismo. Conferir Alves (2003, p.109-110).

21 A última seção da obra intitula-se "As greves e as coalizões de operários".

22 É na referida obra que, conforme notaram Netto (2009) e Mehring (2013), Marx opera a liquidação teórica do socialismo utópicoreformista.

${ }^{23} \mathrm{O}$ título original da obra de Proudhon é Sistema de Contradições econômicas ou filosofia da miséria, ao passo que o título da obra marxiana é Miséria da Filosofia: resposta à Filosofia da Miséria, do sr. Proudhon. Para uma contextualização das obras e das relações entre Marx e Proudhon, conferir Netto (2009).

${ }^{24}$ Ferdinand Lassale dizia que a luta por aumento dos salários era desnecessária, representaria um desvio em relação ao objetivo político dos trabalhadores, a saber, a conquista do poder político no Estado.

${ }_{25}$ Tanto em Miséria da Filosofia como em A Sagrada Família, em que Marx destina a seção inteira de um capítulo para criticar as formulações teóricas de Proudhon, fica evidente o entendimento de que este autor flerta com pontos de vista da Economia Política liberal.

${ }^{26}$ Carta de 24 de setembro de 1852.

${ }^{27}$ Conferir Marx em entrevista com o correspondente do Word, 12 de agosto de 1871.

28 Trata-se da tendência de conciliação de classes no terreno sindical. Em resposta a uma carta de Marx, Engels procura explicar as tendências conciliadoras de um dirigente cartista, Jones, que defendia uma aliança com a burguesia liberal, atribuindo, para isso, como justificativa, certa tendência ao aburguesamento por parte de setores do proletariado inglês, uma vez que as concessões e o predomínio de negociações conciliadoras no movimento operário na Inglaterra estaria produzindo uma "aristocracia operária" aburguesada, que se limitaria ao campo reformista.

${ }^{29}$ Contudo, o Primeiro Congresso da I Internacional ocorreu entre 3 e 8 de setembro de 1866, na cidade de Genebra, contando com sessenta delegados da Inglaterra, França, Alemanha e Suíça, não contando com a presença de Marx. Apesar de sua ausência, Marx preparou as suas resoluções e as encaminhou aos dirigentes do Comitê Central, os quais conseguiram derrotar politicamente o grupo dos mutualistas, que por sua vez defendiam que "o trabalhador seria, ao mesmo tempo, trabalhador, capitalista e consumidor" (MUSTO, 2014 p. 32), sustentado por um sistema de concessão de crédito gratuito enquanto medida de transformação do capitalismo, além de condenarem qualquer regulamentação do Estado no que se refere à relação trabalho $\mathrm{x}$ capital, inclusive no âmbito da redução da jornada de trabalho - identificado tais medidas, erroneamente, como elemento de fortalecimento do poder governamental em detrimento do interesse dos trabalhadores.

30 "Foi Marx quem deu uma finalidade clara à Internacional, quem realizou um programa político não excludente, embora firmemente classista, como garantia de uma organização que ambicionava ser de massas e não sectária. Marx foi a alma política de seu Conselho Geral, aquele que redigiu todas as suas resoluções principais e compilou todos os relatórios preparatórios para os congressos" (MUSTO, 2014, p.23).

31 Para um balanço das polêmicas fracionais e rupturas no interior da I Internacional, conferir o texto de Marx e Engels, de 1872, "As Pretensas Cisões na Internacional: circular privada do Conselho Geral da Associação Internacional dos Trabalhadores", disponível em: MARX e ENGELS (1982).

32 Trata-se de um relatório de Marx preparado para as reuniões do Conselho Geral da Associação Internacional dos Trabalhadores, primeira oportunidade em que Marx introduz as bases teóricas para a teoria da mais-valia.

33 Marx utiliza a expressão "relação de força dos combatentes" (MARX, 2010 p.137) para se referir ao conflito envolvendo a resistência dos trabalhadores assalariados em defesa da limitação da jornada de trabalho contra os capitalistas ávidos em busca de mais-valia.

${ }^{34}$ No texto em foco, Marx aborda o poder das lutas sindicais, seus limites e a natureza desses limites dentro do regime de trabalho assalariado. Assim, as lutas sindicais"(...) são deficientes, de modo geral, por se limitarem a uma luta de guerrilhas contra os efeitos do sistema existente, em lugar de, ao mesmo tempo, se esforçarem para transformá-lo, em lugar de empregarem suas forças organizadas para a emancipação final da classe operária, isto é, para a abolição definitiva do sistema de trabalho assalariado" (MARX, 2010 p.141)

${ }^{35}$ Conforme aponta o relatório de uma seção mutualista francesa (Relatório da seção de Liège sobre as greves): “A greve é uma luta. Portanto, ela aumenta os fomentos de ódios lançados entre o povo e a burguesia e separa cada vez mais duas classes que, em vez disso, deveriam fundir-se e se unir uma com a outra" (MUSTO, 2014 p.38).

36 A partir de então, Marx teve que se empenhar para obstaculizar a crescente influência do anarco-coletivista Bakunin nas fileiras da Internacional, que viria a se constituir como oposição no interior da Internacional, tendo inclusive sido votado sua expulsão da mesma, no Congresso de Haia 1872, em função de Bakunin ter formado uma organização secreta para disputar a direção política da Internacional por meio de táticas conspirativas e adesão a estatutos completamente opostos aos da Internacional. O referido Congresso produziu longo relatório (redigido por Marx, Engels e Lafarque, publicado em 1873), intitulado A Aliança da Democracia Socialista e a Associação Internacional dos Trabalhadores, em que se expõe as atividades secretas da organização liderada por Bakunin. A I Internacional seria dissolvida em 1878, embora tenha emplodido já em 1872, após o Congresso de Haia. A partir de sua dissolução, com um novo Conselho Geral sediado em Nova York e sem a direção da linha política de Marx York - Marx e Engels resolvem abandonar suas funções dirigentes na organização -, o que restou da Internacional se subdividiu na disputa entre “centralistas" e "autonomistas". Conforme aponta Musto (2014 p. 81): "Segundo Marx, porém, a 'primeira' Internacional havia cumprido sua missão histórica e era chegada a hora de baixar a cortina".

37 Resolução da Associação Internacional dos Trabalhadores sobre os Sindicatos, redigida por Marx e aprovada no Congresso de Genebra, em 1866.

Germinal: Marxismo e Educação em Debate, Salvador, v. 12, n. 3, p. 280-295, deそ. 2020. ISSN: 2175-5604 
38 Ajuda da Internacional ao Movimento Sindical, Karl Marx, entrevista ao Word, 12.8.1871.

39 Marx nota que a maioria dos trabalhadores que eram sindicalizados eram trabalhadores qualificados, segmento que constituía, em sua época, a minoria dos trabalhadores assalariados.

${ }^{40}$ Como é sabido, o trabalho abstrato é produtor de valor, a despeito das vastas heterogeneidades dos valores de uso e das formas concretas de trabalho.

${ }^{41}$ Em O Capital, Marx revela os processos históricos e sociais que ocorrem para além da aparência superficial dos fenômenos relativos à produção das riquezas (categoria geral expressa por uma categoria particular, a saber, a mercadoria), uma vez que a universalidade abstrata é decisiva para se conhecer as formas individualizadas.

${ }^{42} \mathrm{Na}$ seção 4 do primeiro capítulo relativo ao Vol.1 de O Capital, Marx aborda o caráter fetichista da mercadoria enquanto ferramenta analítica fundamental para desvendar os "mistérios" (ou segredos) da economia política capitalista. O resultado é que as relações sociais que envolvem as atividades laborais são dissimuladas em relação as coisas. "O caráter misterioso da forma-mercadoria consiste, portanto, simplesmente no fato de que ela reflete aos homens os caracteres sociais de seu próprio trabalho como caracteres objetivos dos próprios produtos do trabalho, como propriedades sociais que são naturais a essas coisas e, por isso, reflete também a relação social dos produtores com o trabalho total como uma relação coisal entre os objetos, existente à margem dos produtores" (MARX, 2013 p.147).

${ }^{43}$ Processo que Marx denomina por “ditadura do proletariado". Importante não confundir, aqui, o termo ditadura com os regimes políticos e formas de governos autoritários que a ciência política no século XX irá denominar por ditadura. Em Marx, o termo expressa o caráter de classe do Estado e dos governos que os gerenciam. No capitalismo ocorreria uma "ditadura" dos interesses da burguesia, ao passo que em um estado operário, a imposição dos interesses dos trabalhadores prevaleceria, imposta às classes dominantes. Por isso, na tradição marxista recente, alguns autores utilizam o termo "ditadura democrática do proletariado".

44 "Naquela época, Marx e Engels conheceram o sindicalismo de ofício, caracterizado por forte exclusivismo profissional, um sindicato que se constituiu em torno de um mesmo ofício e não da empresa (...)", ao passo que o sindicalismo de indústria consiste num "tipo de organização sindical que, caracterizado como sindicalismo de massa, se manifestaria com mais clareza durante o capitalismo do século XX, onde os sindicatos adquiririram, particularmente no pós-II Guerra Mundial, uma posição de destaque no cenário industrial mais desenvolvido" (ALVES, 2003, p.19).

45 Dentre as formas de ação direta reivindicadas pelo "sindicalismo revolucionário" destacam-se aquelas oriundas da organização espontânea do proletariado, como a greve, a "greve geral insurrecional", o boicote, a sabotagem na produção, a agitação e as manifestações contra o Estado e os patrões.

Recebido em: 28.09.2020

Aprovado em: 17.11 .2020 